\title{
A kit to facilitate and standardize the processing of sputum for measurements of airway inflammation
}

\author{
Simone Chaboillez RT ${ }^{1}$, Angira Dasgupta MD MRCPUK², Philippe Prince MSc ${ }^{3}$, \\ Louis-Philippe Boulet MD FRCPC ${ }^{3}$, Catherine Lemière MD MSc ${ }^{1}$
}

S Chaboillez, A Dasgupta, P Prince, L-P Boulet, C Lemière. A kit to facilitate and standardize the processing of sputum for measurements of airway inflammation. Can Respir J 2013;20(4): 248-252.

BACKGROUND: The use of inflammometry has been shown to be effective for managing asthma. However, sputum processing can be time consuming. Furthermore, methods of sputum processing can vary among facilities. To help with standardization and to simplify the procedure for laboratory staff, a novel, commercially available processing device (Accufilter, Cellometrics Inc, Canada) has been developed.

OBJECTIVE: To assess the validity of the Accufilter device and kit for recovery of treated specimens, and for quantitative sputum inflammatory cell counts by comparing intrasample measurements with those using the same procedure without the Accufilter device and kit.

METHODS: The present study was a wet laboratory comparison of induced sputum cell counts obtained from sputum processed with versus without the device and kit. Comparisons of each sputum specimen were performed by the same technologist in random order.

RESULTS: A total of 39 samples were processed using both the standard method and the Accufilter device. The intraclass correlation coefficients were high for the weight of the filtrate, and for eosinophil and neutrophil differential counts.

CONCLUSION: A good degree of agreement of results was apparent when the two methods were compared. The differences noted between both methods were minimal and did not modify clinical interpretation. The use of the Accufilter device and kit can be used in place of the standard method for sputum quantitative analysis, especially in centres with large sample loads.

Key Words: Method standardization; Sputum cell counts; Sputum processing

$\Delta$ irway inflammation is an important component of obstructive Aairway diseases. Depending on its cellular nature, it may be of different causes and types. Recognizing the various types of airway inflamation is important because they require different treatment approaches. The cellular component of airway inflammation can be measured objectively by spontaneous or induced sputum quantitative cell count, which is recognized to be the most direct, noninvasive, specific, comprehensive and discriminative method currently available (1). Sputum cell counts have been shown to be useful in clinical practice (2-3), research (4-6) and in clinical trials to investigate and select patients, or to examine the effect of anti-inflammatory drugs (7-9). In clinical practice, sputum cell counts are especially useful to guide treatment of severe, difficult-to-control or complicated disease as emphasized by the most recent Canadian guidelines (10); hence, they are more likely to be of use to specialists.

In clinical practice, the processing and examination of sputum requires a certified medical laboratory technologist, a standardized procedure and a system for regular quality control (2). To help with standardization and to simplify the procedure for laboratory staff, a novel, commercially available processing device (Accufilter, Cellometrics Inc, Canada) has been developed. It consists of a

\author{
Une trousse pour faciliter et standardiser le \\ traitement des expectorations a fin de mesurer \\ l'inflammation des voies respiratoires
}

HISTORIQUE : Il est démontré que l'inflammométrie est efficace pour
prendre l'asthme en charge. Cependant, le traitement des expectorations
peut être chronophage, et les méthodes de traitement des expectorations
varient selon les établissements. Afin de standardiser et de simplifier le
processus pour le personnel de laboratoire, un nouveau dispositif de traite-
ment commercial (Accufilter, Cellometrics Inc., Canada) a été mis au point.

OBJECTIF : Évaluer l'efficacité du dispositif et de la trousse Accufilter pour récupérer les échantillons traités et procéder à la numération quantitative des cellules inflammatoires dans les expectorations en comparant les mesures intra-échantillons avec celles faisant appel au même processus, sans le dispositif et la trousse Accufilter.

MÉTHODOLOGIE : La présente étude était une comparaison en laboratoire humide des numérations des cellules d'expectorations induites obtenues dans les expectorations traitées à l'aide et sans l'aide du dispositif et de la trousse. Le même technologue a comparé chaque échantillon d'expectorations dans un ordre aléatoire.

RÉSULTATS : Au total, 39 échantillons ont été traités au moyen de la méthode standard et du dispositif Accufilter. Les coefficients de corrélation intraclasse étaient élevés d'après le poids du filtrat et les numérations différentielles des éosinophiles et des neutrophiles.

CONCLUSION : La comparaison des deux méthodes révèle un bon degré de concordance des résultats. Les différences entre les deux méthodes étaient minimes et ne modifiaient pas l'interprétation clinique. L'utilisation du dispositif et de la trousse Accufilter peu remplacer la méthode standard d'analyse quantitative des expectorations, notamment dans les centres ayant un débit élevé d'échantillons.

collection tube (into which sputum selected from saliva is weighed and treated), a filter conduit (through which the treated sputum passes) and a reception tube that receives a homogenous suspension of sputum cells. The device is made available in a kit, which also contains dithiothreitol (DTT) and saline to treat the sputum, trypan blue to assess cell viability and an insert with a detailed description of the procedure. The suspension of sputum cells obtained after treatment and filtration through the filter conduit can then be examined in a hemocytometer for total cell count and cell viability, and on stained cytospins for cell differential. The fluid phase can be collected for molecular inflammatory indexes and proteomic analysis when these are needed. The cell pellet can also yield RNA for genomic research.

In the present study, we investigated the validity of the Accufilter device and kit for recovery of treated specimens, and for quantitative sputum inflammatory cell counts by comparing intrasample measurements with those using the same procedure without the device. To eliminate possible differences in results due to reagents within the kit, such as DTT, which need to be freshly prepared for best results, we also performed a second smaller study using DTT from the same external source for both methods. The two processing methods adopted were otherwise similar to the former study.

${ }^{1}$ Hôpital du Sacré-Cour de Montréal, Université de Montréal, Montréal, Québec; ${ }^{2}$ BR Singh Hospital and Centre for Medical Education and Research, Kolkata, West Bengal, India; ${ }^{3}$ Unité de recherche en pneumologie, Institut universitaire de cardiologie et de pneumologie de Québec, Québec, Québec 


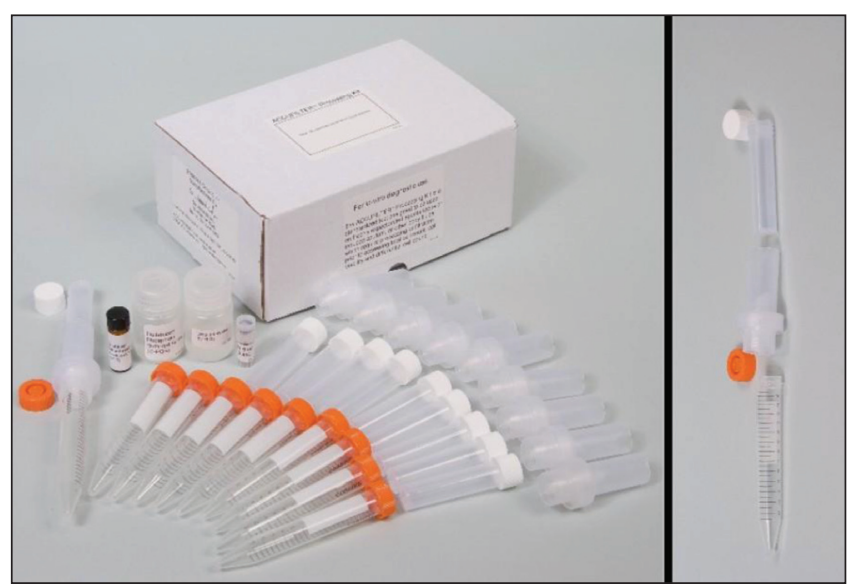

Figure 1) The Accufilter (Cellometrics Inc, Canada) device

\section{METHODS}

Study design

The present study was a wet laboratory comparison of induced sputum cell counts obtained from sputum processed using the Accufilter device and kit, with sputum processed by the standard method as described by Pizzichini et al (11). Comparisons of each sputum specimen were performed by the same technologist in random order. The study was approved by the Hospital Research Ethics Committee of Hôpital du Sacré-Coeur de Montréal, Montreal (Quebec) and Institut universitaire de cardiologie et de pneumologie de Québec, Quebec City (Quebec).

\section{Source of sputum}

Induced sputum was obtained from patients with obstructive airway diseases such as asthma or chronic obstructive pulmonary disease, or patients with chronic cough. The physician diagnosis, although not relevant to the study, was recorded without documentation of subject characteristics. If there was sufficient material to allow two portions of the specimen to be examined, it was used for comparison of the two procedures in the study.

\section{Sputum processing and examination method}

All sputum samples were processed by certified medical laboratory technologists trained in sputum examination for cell counts and morphology. The research laboratories used for the present study had internal and external quality control measures for total and differential cell counts in place.

Sputum was carefully selected using an inverted microscope to exclude as many salivary squamous cells as possible. The selected portion was mixed gently to achieve a consistency as homogeneous as possible. The sample was divided into two similar weights (between $150 \mathrm{mg}$ and $300 \mathrm{mg}$ each), and recorded on worksheets. One portion was labelled as subject ID (A) and the other as subject ID (B) in random order. One portion (A) was processed by the standard method as previously described by Pizzichini et al (11). The other portion (B) of similar weight was processed simultaneously using the Accufilter device and kit. The filtered fluids were measured to compare any retention of fluid in the device or standard apparatus. A manual total cell count and viability assessment was performed twice using a hemocytometer for each processing method and the results recorded. Two cytospins from each of the samples processed by the two separate methods were prepared and air dried. Samples were stained with Wright's stain and a 400-cell differential count was performed on each and the results recorded. The differential on the kit sample was performed on coded slides after five specimens were collected.

\section{Accufilter device}

The Accufilter device is manufactured by Southmedic (Barrie, Ontario). It is approved by Health Canada as an in vitro diagnostic
TABLE 1

Descriptive statistics and interquartile range (IQR) of various parameters of the two methods (standard versus Accufilter*)

\begin{tabular}{|c|c|c|c|}
\hline & $\begin{array}{c}\begin{array}{c}\text { Standard } \\
\text { method }\end{array} \\
\text { Median (IQR) }\end{array}$ & $\begin{array}{c}\begin{array}{c}\text { Accufilter } \\
\text { kit }\end{array} \\
\text { Median (IQR) }\end{array}$ & ICC (95\% CI) \\
\hline Weight of filtrate $^{\dagger}, \mathrm{g}$ & $0.16 \pm 0.06$ & $0.16 \pm 0.06$ & $0.99(0.996-0.99)$ \\
\hline $\begin{array}{l}\text { Total cell count, } \\
\times 10^{6} \mathrm{cell} / \mathrm{s} / \mathrm{g}\end{array}$ & $3.44(4.68)$ & $1.2(2.32)$ & $0.72(0.36-0.86)$ \\
\hline Viability, \% & $74.2(27)$ & $50.9(35.8)$ & $0.5(-0.12-0.77)$ \\
\hline Neutrophils, \% & $38.1(51.1)$ & $21.3(46.6)$ & $0.86(0.34-0.95)$ \\
\hline Eosinophils, \% & $1.25(7.0)$ & $0.5(7.19)$ & $0.89(0.79-0.95)$ \\
\hline Squamous cells, $\%$ & $4.3(8.08)$ & $6.1(14.3)$ & $0.68(0.35-0.84)$ \\
\hline Macrophages, \% & $32.5(37.5)$ & $43.1(40.8)$ & $0.88(0.64-0.95)$ \\
\hline Lymphocytes, \% & $0.5(1)$ & $0.0(0.7)$ & $0.85(0.55-0.94)$ \\
\hline $\begin{array}{l}\text { Bronchial epithelial } \\
\text { cells, \% }\end{array}$ & $3.5(12.5)$ & $6.5(16)$ & $0.83(0.53-0.93)$ \\
\hline
\end{tabular}

device and is a registered trademark. The device and kit is currently made available by Cellometrics Inc (Hamilton, Ontario) at a cost of CAD $\$ 20.00$, but was developed through research at St Joseph's Healthcare, Hamilton, who provided it for the present study (Figure 1).

Statistical analysis and sample size

Cell counts were expressed as median and interquartile range. Weight of filtrate recovered was expressed as mean $\pm \mathrm{SD}$. To determine agreement between the Accufilter and standard method, differences between the Accufilter (test method) and standard method for clinically important cell counts (total cell count, neutrophil percentages and eosinophil percentages) and weight of filtrate were calculated (standard minus test). Agreement between counts performed by the standard manual method and Accufilter kit method were assessed using the reliability coefficient or intraclass correlation coefficient (ICC), and also as proposed by Bland and Altman (12). ICC values $>0.9$ were regarded as good agreement. SPSS version 19 (IBM Corporation, USA) was used for data analysis.

It was estimated that approximately 40 specimens, in which a total and differential cell count could be obtained, would be required to identify an ICC of 0.9 between two raters with at least $80 \%$ power.

Study 1

\section{RESULTS}

A total of 39 samples were processed using both the standard method and the Accufilter device. The median and interquartile range of total cell counts, viable cell, neutrophil, eosinophil, squamous cell, macrophage, lymphocytes, and bronchial epithelial cells percentages as well as weight of filtrate (mean \pm SD) using both methods is presented in Table 1 . The overall ICCs are high for weight of the filtrate, eosinophil, neutrophil, macrophage and lymphocyte counts. The ICC for the total cell count was 0.72 .

The mean of the differences between the results by the two methods and the corresponding SDs are tabulated in Table 2. The $95 \%$ limits of agreement were $-0.01 \mathrm{~g}$ to $0.01 \mathrm{~g}$ for the weight of the filtrate, $-3.5 \times 10^{6}$ cells/g to $8.2 \times 10^{6}$ cells/g of sputum for the total cell count (Figure 2B) while those for neutrophil and eosinophil were $-19 \%$ to $52.3 \%$ (Figure 2C) and $-8.69 \%$ to $8.41 \%$ (Figure 2D), respectively.

\section{Study 2}

A total of 13 samples were processed by both methods using freshly prepared DTT from an external source. The median, interquartile ranges and ICCs of the various cell counts and weight of the filtrate $($ mean \pm SD) are tabulated in Table 3 . 
TABLE 2

Standard versus Accufilter* process using dithiothreitol (DTT) from kit and external source

\begin{tabular}{|c|c|c|c|c|c|c|}
\hline & \multicolumn{3}{|c|}{ DTT from kit } & \multicolumn{3}{|c|}{ External DTT } \\
\hline & $\begin{array}{c}\text { Mean difference } \\
\text { between methods }\end{array}$ & SD & $\begin{array}{c}95 \% \text { limits of } \\
\text { agreement }\end{array}$ & $\begin{array}{c}\text { Mean difference } \\
\text { between methods }\end{array}$ & SD & $\begin{array}{c}95 \% \text { limits of } \\
\text { agreement }\end{array}$ \\
\hline Weight of filtrate, $\mathrm{g}$ & -0.0004 & 0.005 & -0.01 to 0.01 & 0.001 & 0.0034 & -0.005 to 0.008 \\
\hline Neutrophils, \% & 16.67 & 17.8 & -19 to 52.3 & 0.06 & 9.3 & -12.5 to 24.6 \\
\hline Eosinophils, \% & -0.13 & 4.27 & -8.69 to 8.41 & 0.78 & 2.13 & -3.47 to 5.04 \\
\hline
\end{tabular}

*Cellometrics Inc, Canada

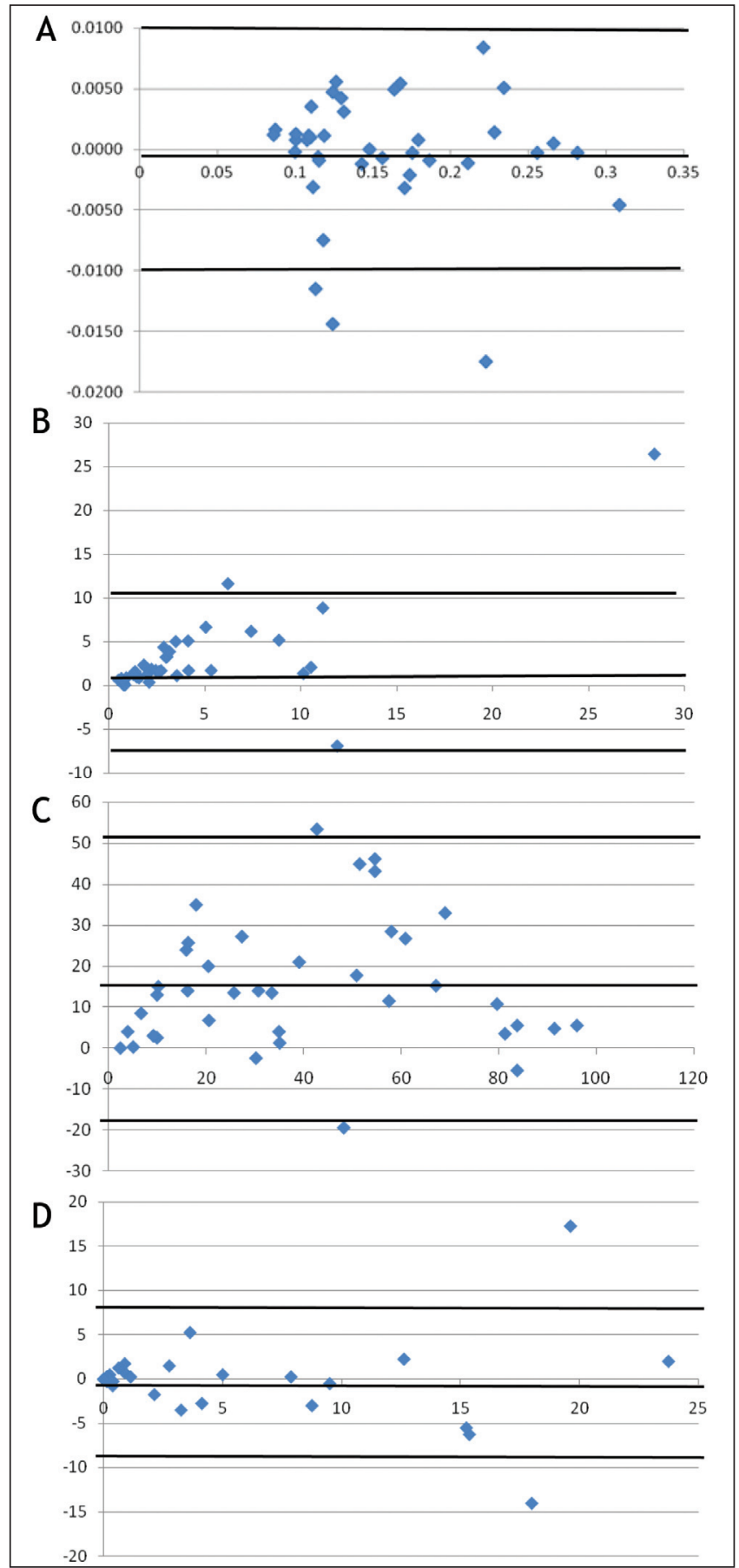

Figure 2) A Weight of filtrate: difference (standard minus test) versus average of the two methods. B Total cell counts: difference (standard minus test) versus average of two methods. C Neutrophil percentages: difference (standard minus test) versus average of two methods. D Eosinophil percentages: difference (standard minus test) versus average of two methods
TABLE 3

Descriptive statistics and interquartile range (IQR) of various parameters of the two methods (standard versus Accufilter*) using dithiothreitol (DTT) from an external source

\begin{tabular}{|c|c|c|c|}
\hline & $\begin{array}{c}\text { Standard } \\
\text { method }\end{array}$ & $\begin{array}{c}\text { Accufilter kit } \\
\text { (external } \\
\text { source DTT) } \\
\end{array}$ & \\
\hline & Median (IQR) & Median (IQR) & ICC (95\% Cl) \\
\hline Weight of filtrate $^{\dagger}, \mathrm{g}$ & $0.16 \pm 0.05$ & $0.16 \pm 0.05$ & $0.99(0.99-1.0)$ \\
\hline $\begin{array}{l}\text { Total cell count, } \\
\times 10^{6} \mathrm{cells} / \mathrm{g}\end{array}$ & $2.5(5.61)$ & $1.5(5.98)$ & $0.93(0.75-0.97)$ \\
\hline Viability, \% & $78.8(22.0)$ & $70.3(25.1)$ & $0.81(0.41-0.94)$ \\
\hline Neutrophils, \% & $38.2(53.8)$ & $31.2(66.5)$ & $0.97(0.88-0.99)$ \\
\hline Eosinophils, \% & $0.25(7.13)$ & $0.50(2.75)$ & $0.92(0.75-0.97)$ \\
\hline Squamous cells, \% & $4.3(8.53)$ & $5.7(10.43)$ & $0.9(0.67-0.97)$ \\
\hline Macrophages, \% & $42.0(50.63)$ & $44(58)$ & $0.96(0.85-0.99)$ \\
\hline Lymphocytes, \% & $0.50(0.50)$ & $0.50(1.25)$ & $0.015(-2.2-0.7)$ \\
\hline Bronchial epithelial & $2.0(8.38)$ & 2.25 (11.38) & $0.97(0.89-0.99)$ \\
\hline
\end{tabular}

cells \%

${ }^{*}$ Cellometrics Inc, Canada; ${ }^{\dagger}$ Mean \pm SD. ICC Intraclass correlation coefficient

An agreement analysis was performed for the weight of the filtrate and total cell counts, and neutrophil and eosinophil percentages using the Bland-Altman method. The mean of the differences between the results of the two methods, SDs and 95\% limits of agreement are tabulated in Table 3. Figures 3A to 3D show Bland-Altman plots of the difference versus mean of the two measurements.

\section{DISCUSSION}

The clinical importance of sputum quantitative assays in the management of airway diseases warrants the need for a rapid and simple method for sputum processing, such as the Accufilter device and kit, especially for centres that handle large numbers of samples. The Accufilter device and kit are the first of their kind, and the present study was the first to validate its use in place of the standard method.

In the late 1980s and early 1990s, Gibson et al (13) and Pin et al (14) demonstrated that it was possible to obtain differential cell counts from smears of sputum produced spontaneously or induced with an aerosol in a reproducible, responsive and validated way. However, the use of smears was disadvantageous because cellular definition was poor, making differentiating eosinophils from neutrophils difficult. The process, therefore, became very time consuming. Subsequently, cell counting was improved by the treatment of sputum with DTT to disperse mucus and by the use of cytospins to facilitate cell dispersion (15). The method was further improved by the use of the inverted microscope, which helped to select squamous cell contamination-free parts of the sputum sample; however, this method still required filtration of the treated sputum through a nylon mesh over a funnel. The Accufilter device and kit is an improvement on this in that it incorporates a collection tube, a filter conduit and a receiving tube into one simple, convenient device. The device is disposable and, therefore, sterilization is not required. This makes the process $30 \mathrm{~min}$ faster and 


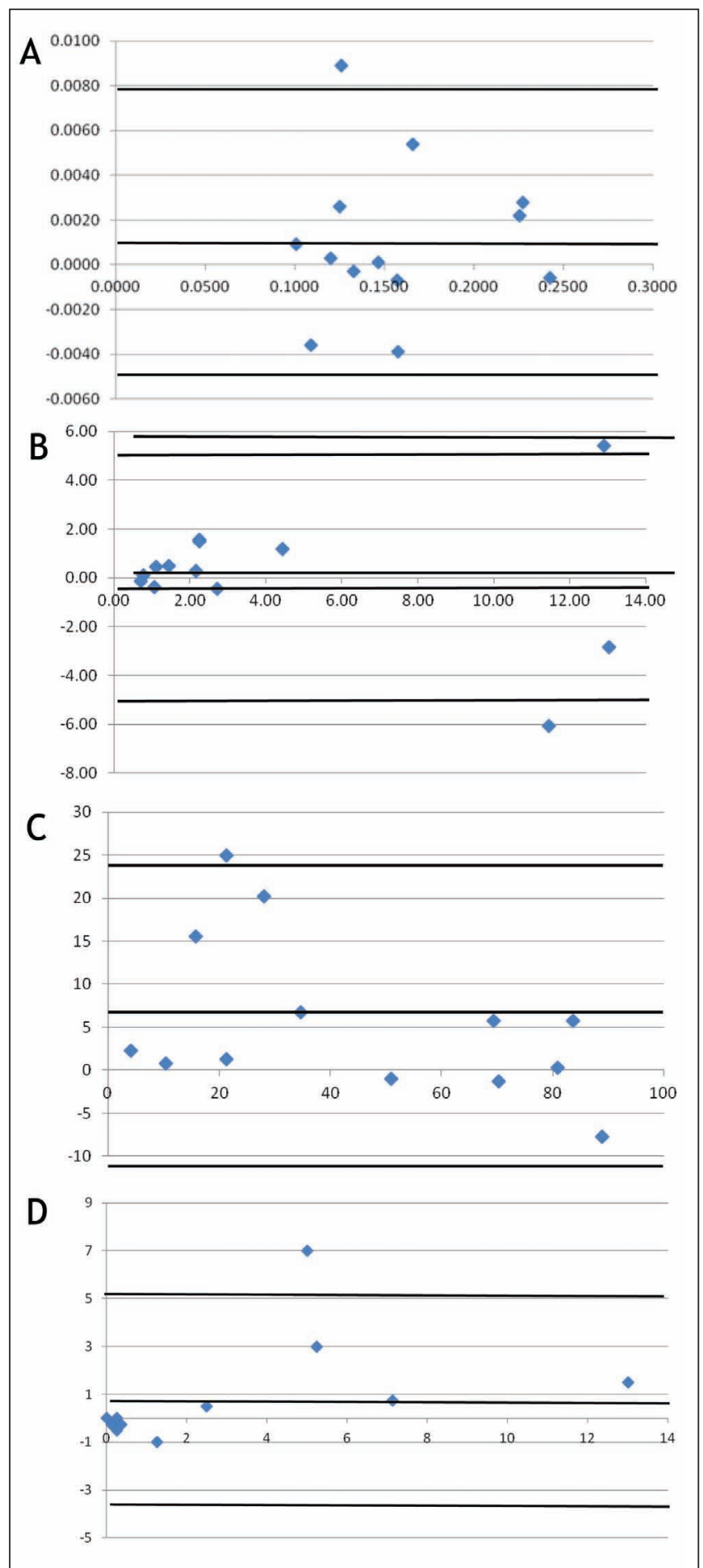

Figure 3) A Weight of filtrate: difference (standard minus test) versus average of two methods using external source of dithiothreitol (DTT). B Total cell counts: difference (standard minus test) versus average of two methods using external source of DTT. C Neutrophil percentages: difference (standard minus test) versus average of two methods using external source of DTT. D Eosinophil percentages: difference (standard minus test) versus average of two methods using external source of DTT

simpler to perform because there is no need to assemble and sterilize the various apparatus required by the standard process. The present study demonstrated that the use of the Accufilter device and kit provides results as good as the standard method. Because the cost of the Accufilter $(\$ 20)$ is similar to the cost of the usual procedure $(\$ 20.80)$
TABLE 4

95\% limits of agreement of the two methods compared with the repeatability data in Pizzichini et al (18), 1996

\begin{tabular}{lccc}
\hline Cells & $\begin{array}{c}\text { Pizzichini } \\
\text { et al (18), 1996 }\end{array}$ & $\begin{array}{c}\text { Standard } \\
\text { vs kit }\end{array}$ & $\begin{array}{c}\text { Standard vs kit (with } \\
\text { external source of DTT) }\end{array}$ \\
\hline $\begin{array}{c}\text { Eosinophils, } \\
\text { log scale* }\end{array}$ & -1.5 to +1.5 & -1.5 to +1.55 & -1.9 to +1.2 \\
Neutrophils & $-28 \%$ to $+28 \%$ & $-19 \%$ to $52.3 \%$ & $-12.5 \%$ to $24.6 \%$ \\
\hline
\end{tabular}

*Eosinophil limits expressed in log scale to compare with data in the original article. DTT Dithiothreitol; vs Versus

(16), we believe that the use of Accufilter represents a cost-effective alternative for sputum processing.

In the present study, the ICCs were high for the weight of the filtrate in both the methods using either DTT from the kit or from an external source. This suggests that the device is extremely efficient in its filtering function. Moreover, the ICCs for eosinophil and neutrophil differential counts were high in both studies, thus indicating that the method using the Accufilter device and kit was as effective as the standard method in obtaining differential counts. The ICC of the total cell count was 0.72 in study 1 , which could be a reflection of the variation in the number of cells in different portions of the expectorated specimen. The fact that the ICC for total cell counts in study 2 was 0.93 further supports this. The ICCs for squamous cells (in study 1 only), lymphocytes and viability counts were also low. The low viability obtained when using the DTT provided in the kit questions its equivalence to the freshly prepared DTT used in the standard procedure. Two millilitres of DTT are provided in the Accufilter kit in a small jar. The preservation of DTT in a tiny jar may not be as effective as in a large container, especially when the jar has been opened. The probable reason for this is that the stability of DTT is compromised on exposure to air. This leads to incomplete release of cells from the mucus of the sputum sample. Such an effect may result in low viability counts and may cause cells to stain darkly making their correct identification difficult (17). This, however, will require further investigation.

The results showed good agreement for total cell counts and weight of the filtrate (Table 3) in both studies but the 95\% CIs in the agreement analysis for the neutrophils and eosinophils were wide. However, these values compare well with the repeatability of these counts by the standard method as reported by Pizzichini et al (18) (Table 4). Whatever little differences are noted could very well be due to differences in the cellular content of different portions of the same sample.

The present study had limitations. First, the range of total cell counts $\left(0.82 \times 10^{6}\right.$ cells/g to $41.7 \times 10^{6}$ cells/g) and eosinophil counts $(0 \%$ to $24.75 \%)$ in the samples examined were not entirely representative of those seen in clinical practice, where higher total cell counts and eosinophil counts are frequently encountered. Therefore, the validity of the Accufilter device in such circumstances needs to be further evaluated. Second, the tests for a particular sample were performed by a single technologist. It would have been ideal if there were two technologists involved, each performing both methods on the same samples, so that there would have been two sets of data. Given that the quantity of sputum samples were typically small, it would have been difficult and practically not feasible to split the sputum samples into four portions.

Despite these limitations, the results of the present study provide sufficient evidence to justify and recommend the use of a highthroughput method such as the Accufilter device, especially in centres with large sample loads.

DISCLOSURES: The authors have no financial disclosures or conflicts of interest to declare.

FUNDING: Firestone Institute of Respiratory Health Internal funds. 


\section{REFERENCES}

1. Nair PK, Hargreave FE. Airway diseases, inflammometry and individualized therapy. In: Polosa R, Holgate ST, eds. Therapeutic Strategies in Asthma: Current Treatments. Oxford: Clinical Publishing, 2007:155-64.

2. Nair P, Hargreave FE. Measuring bronchitis in airway diseases: Clinical implementation and applications. Chest 2010;138(2 Suppl):38S-43S.

3. Siddiqui S, Brightling CE, Airway disease: Phenotyping heterogeneity using measures of airway inflammation. J Allergy Asthm Clin Immunol 2007;3:60-9.

4. Lemiere C, Pizzichini MM, Balissoon R, et al. Diagnosing occupational asthma: Use of induced sputum. Eur Resp J 1999;13:482-8.

5. Girard F, Chaboillez S, Cartier A, et al. An effective strategy for diagnosing occupational asthma: Use of induced sputum. Am J Respir Crit Care Med 2004;170:845-50.

6. Lemiere C, D'Alpaos V, Chaboillez S, et al. Investigation of occupational asthma: Induced sputum or exhaled NO? Chest 2010;137:617-22

7. Jayaram L, Pizzichini MM, Cook RJ, et al. Determining asthma treatment by monitoring sputum cell counts: Effect on exacerbations. Eur Resp J 2006;27:483-94.

8. Nair P, Pizzichini MM, Kjarsgaard M, et al. Mepolizumab for prednisone-dependent asthma with sputum eosinophilia. N Engl J Med 2009;360:985-93.

9. Haldar P, Brightling CE, Hargadon B, et al. Mepolizumab and exacerbations of refractory eosinophilic asthma. N Engl J Med 2009;360:973-84.
10. Lougheed MD, Lemiere C, Ducharme FM, et al; Canadian Thoracic Society Asthma Clinical Assembly. Canadian Thoracic Society 2012 guideline update: Diagnosis and management of asthma in preschoolers, children and adults. Can Respir J 2012;19:127-64.

11. Pizzichini MM, Popov T, Efthimiadis A, et al. Spontaneous and induced sputum to measure indices of airway inflammation. Am J Respir Crit Care Med 1996;154:866-9.

12. Bland JM, Altman DG. Statistical methods for assessing agreement between two methods of clinical measurement. Lancet 1986;1:307-10.

13. Gibson PG, Girgis-Gabardo A, Morris MM, et al. Cellular characteristics of sputum from patients with asthma and chronic bronchitis. Thorax 1989;44:693-9.

14. Pin I, Gibson PG, Kolendowicz R, et al. Use of induced sputum cell counts to investigate airway inflammation in asthma. Thorax $1992 ; 47: 25-9$.

15. Popov T, Gottschalk R, Kolendowicz R, Dolovich J, Powers P, Hargreave FE. The evaluation of a cell dispersion method of sputum examination. Clin Exp Allergy 1994;24:778-83.

16. D'silva L, Gafni A, Thabane L, et al. Cost analysis of monitoring asthma treatment using sputum cell counts. Can Respir J 2008;15:370-4.

17. Scheicher ME, Terra Filho J, Vianna EO. Sputum induction: Review of literature and proposal for a protocol. Sao Paulo Med J 2003;121:213-9.

18. Pizzichini E, Pizzichini MM, Efthimiadis A, et al. Indices of airway inflammation in induced sputum: Reproducibility and validity of cell and fluid-phase measurements. Am J Respir Crit Care Med 1996;154(2 Pt 1):308-17. 


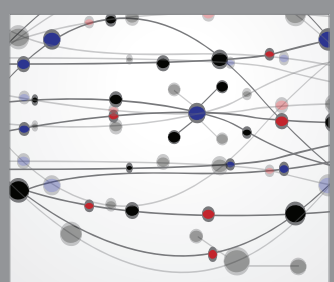

The Scientific World Journal
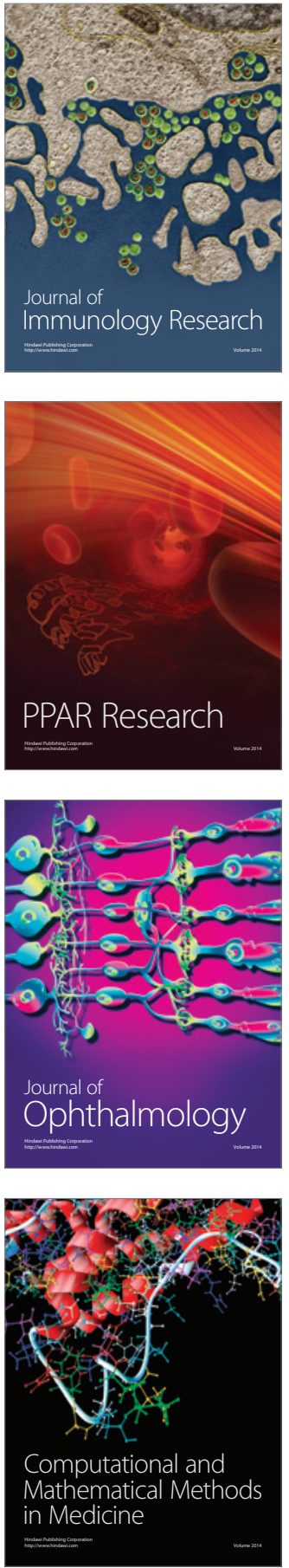

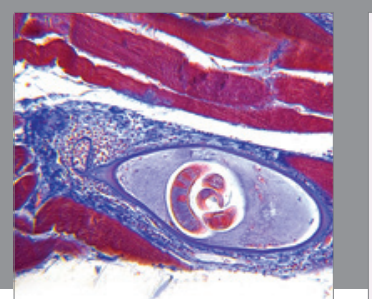

Gastroenterology Research and Practice

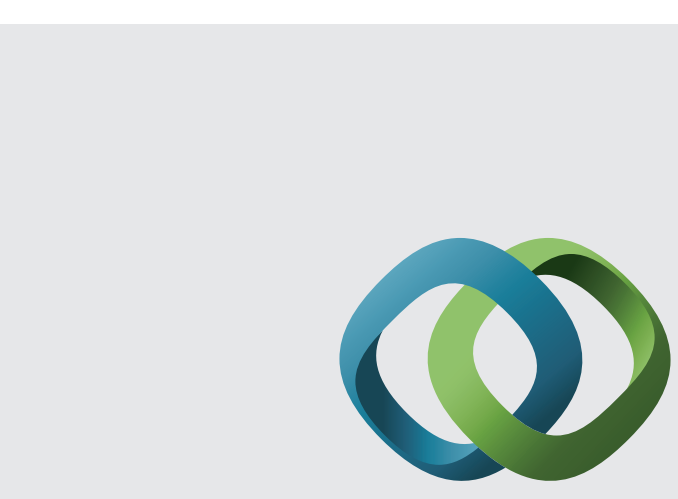

\section{Hindawi}

Submit your manuscripts at

http://www.hindawi.com
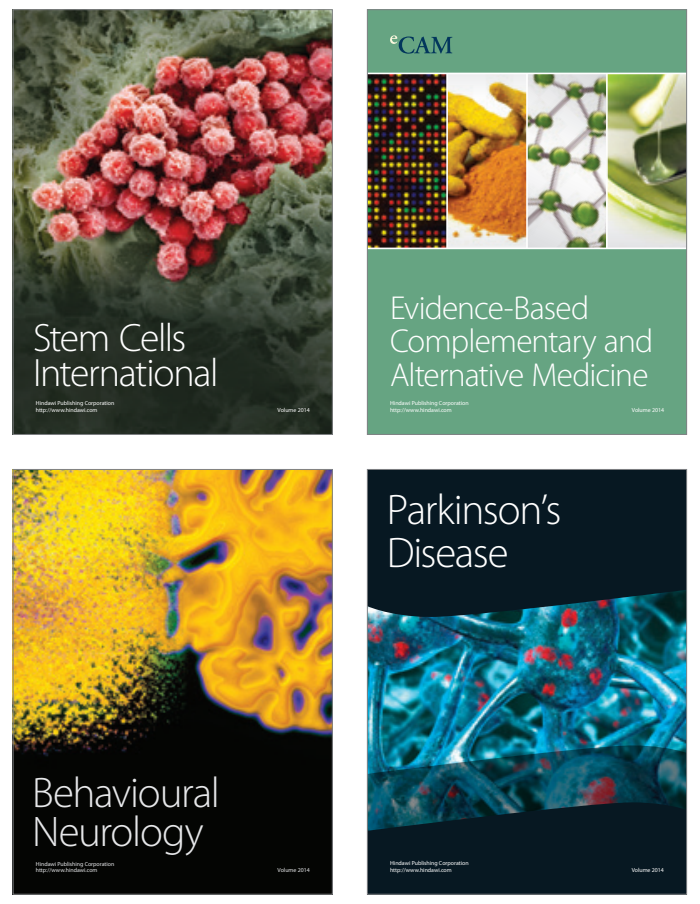
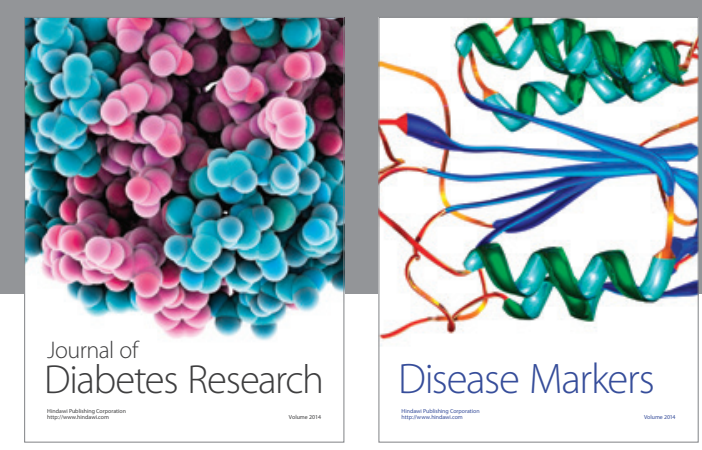

Disease Markers
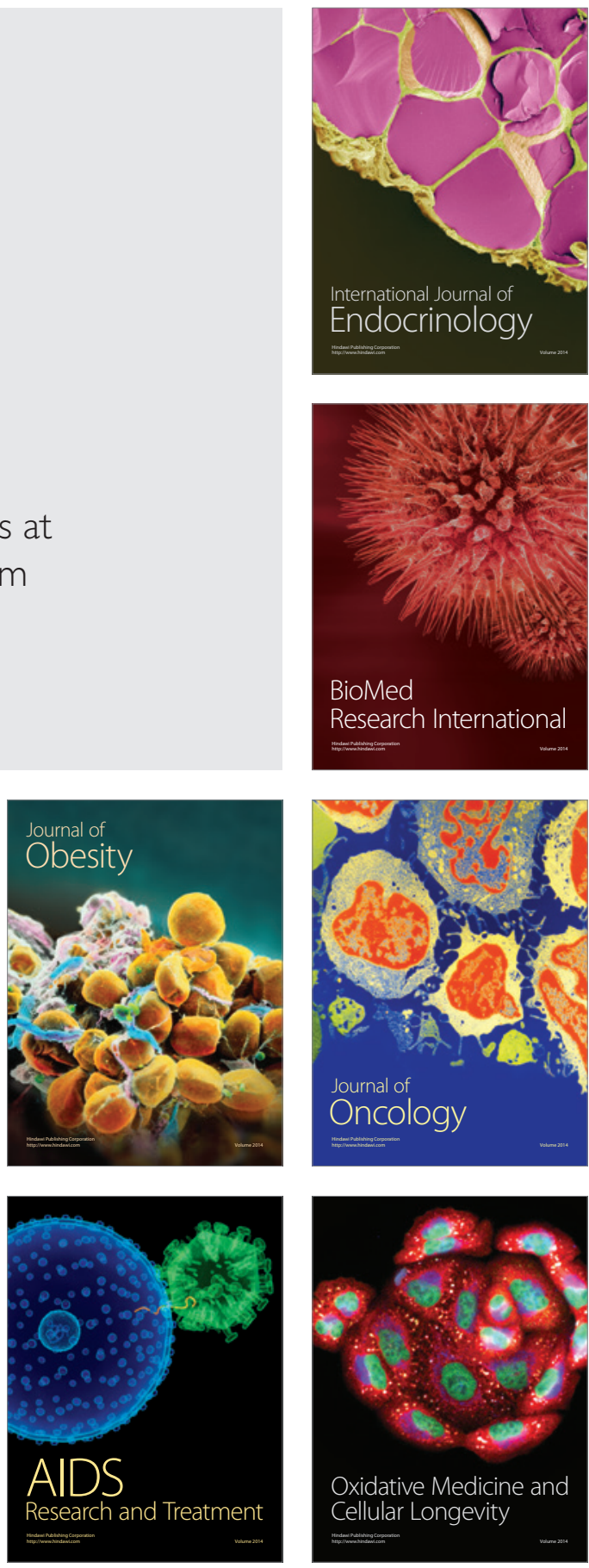